\title{
Manometric Evaluation of Internal Anal Sphincter after Fissurectomy and Anoplasty for Chronic Anal Fissure: A Prospective Study
}

ROSAlia PATti, M.D., Ph.D., VAlentina TERRITO, M.D., PAOLO AIELLO, M.D., GIUSEPPE LIVIO ANGELO, M.D., GAETANO DI VITA, M.D.

From the General Surgery Unit, Department of Surgical and Oncological Sciences, University of Palermo, Palermo, Italy

\begin{abstract}
Chronic anal fissure (CAF) is a common painful clinical disease and its pathogenesis remains poorly understood. After failure of pharmacological therapy, that is the first-line treatment, surgical sphincterotomy remains the treatment of choice although it is followed by a high rate of anal incontinence resulting from the sphincter damage; therefore, the research of a sphincter-saving surgical option has become an important goal. The aim of this study was to evaluate the manometric modifications and the incidence of anal incontinence after fissurectomy and anoplasty with advancement skin flap in patients affected by CAF with hypertonia of the internal anal sphincter (IAS). Fifteen patients affected by CAF with hypertonia of IAS, unresponsive to medical therapy, were enrolled. All subjects underwent fissurectomy and anoplasty with advancement skin flap. Anorectal manometry was performed preoperatively and after 6 and 12 months from surgery. Maximum resting pressure (MRP), maximum squeeze pressure (MSP), ultraslow wave activity (USWA), fissure healing, anal continence, and postoperative complications were recorded. All patients healed within 30 days from surgery. No intra- or postoperative complications were recorded except for a case of partial donor site break. No significant modifications of MSP were detected. Six months after surgery, MRP was higher with respect to healthy subjects but significantly reduced in comparison to baseline levels. At 12 months, it was higher have versus 6-month values but significantly lower versus preoperative values. USWA was significantly represented in patients with CAF versus healthy subject. Both at 6 and 12 months, they decreased significantly with respect to preoperative values without significant differences versus healthy subjects. Both at 6 and 12 months, anal continence did not differ with respect to preoperative time. The fissurectomy with anoplasty resulted in a high healing rate without surgical sequelae or anal incontinence. Also, it was able to reduce IAS pressure in the same manner as surgical sphincterotomy or forceful dilatation.
\end{abstract}

C HRONIC ANAL FISSURE (CAF) is a common painful clinical disease. According to the literature, it seems that CAF affects approximately 10 per cent of patients with proctologic diseases. In England, from 2005 to 2006, the incidence of hospitalization for CAF was 1.56 cases per 10,000 people. ${ }^{1}$ Data obtained from the Italian Centers of Coloproctology during 2009 showed that they observed 5199 patients affected by CAF of whom 1924 (approximately 37\%) underwent surgery. $^{2}$ The pathogenesis of CAF is poorly understood, but it is believed to result from the combination of internal anal sphincter (IAS) hypertonia, relative ischemia, and anal canal trauma. The role of hypertonia

Address correspondence and reprint requests to Gaetano Di Vita, M.D., Director, General Surgery Unit, University of Palermo, Italy, Via Liborio Giuffrè ${ }^{\circ}$ 5, 90100 Palermo, Italy. E-mail: divitagaetano@libero.it. of the IAS in the genesis of CAF remains not well defined. Relief of the spasm has been associated with relief of pain and healing of the fissure. It is now well accepted that the first-line treatment of CAF is pharmacological, although, after the failure of conservative therapy, lateral internal sphincterotomy is considered the treatment of choice for CAF. This procedure is able to reduce permanently the maximum resting pressure (MRP) of the anal canal allowing fissure healing in more than 95 per cent of cases, ${ }^{3}$ but it may be followed by soiling in a significant number of patients. The significant traumatizing complication of incontinence led the surgeons to research for surgical procedures that preserve structural and functional integrity of the IAS and, to date, the fissurectomy results in the procedure being the most commonly used. This technique was recently used alone ${ }^{4-6}$ and associated with a chemical sphincterotomy ${ }^{7-13}$ or it was associated with anoplasty 
using an advancement cutaneous ${ }^{14-24}$ or mucosal flap ${ }^{25}$ with an incidence of healing comparable to lateral internal sphincterotomy. The aim of this study was to evaluate some manometric modifications and the incidence of anal incontinence after fissurectomy and anoplasty with an advancement flap in patients affected by CAF with hypertonia of IAS.

\section{Materials and Methods}

Fifteen male patients affected by posterior CAF with hypertonia of IAS unresponsive to medical treatment were enrolled in this prospective study from November 2009 to December 2010. All subjects gave written informed consent, and the local ethics committee approved the study. Exclusion criteria were the presence of multiple fissures, fistulas in ano, syphilis, inflammatory bowel disease, anal abscess, malignant disease, and previous anorectal surgery. CAF resistant to medical treatment was defined as those that failed to heal after topical medical therapy and a high-fiber dietary supplementation. Preoperative anorectal manometry was performed at least 4 weeks after the cessation of glyceryl trinitrate ointment or calcium channel blocker therapy and at 15 weeks after toxin botulinum injection. A manometric control was repeated 6 and 12 months after surgery. The manometry was carried out by a manometric sensor ( $2.1 \mathrm{~mm}$ external diameter) with four circle orifices and with a latex microballoon at its extremity (Marquat C87; Boissy, St-Leger, France). The machine was connected to a polygraph (Narco; ByoSystem MMS 200, Houston, TX) using the station pullthrough method with perfusion of normal saline and the patient was lying in the right lateral position. CAF with hypertonia was defined as those whose MRP values were higher than $85 \mathrm{mmHg} .{ }^{26} \mathrm{On}$ manometry, MRP and maximum squeeze pressure (MSP) were defined as maximum pressure detected, respectively, on resting and after voluntary contraction. Ultraslow wave activity (USWA) was defined as pressure waves with frequency of less than $2 / \mathrm{min}$ and an amplitude greater than $25 \mathrm{~cm}$ $\mathrm{H}_{2} \mathrm{O}$. All patients underwent fissurectomy and anoplasty with advancement skin flap lying in a gynecological position under spinal anesthesia. After injection of $5 \mathrm{~mL}$ local anesthetic solution (100 mg clonitrate mepivacaine and $0.025 \mathrm{mg} \mathrm{L}$-adrenaline), four Kocher pliers were located in the proximity of mucous-cutaneous junction, respectively, at $3,6,9$, and 12 hours providing good exposure of the anal canal; subsequently, the fibrotic edges were excised with a scalpel until normal nonfibrotic anodermal tissue showed sufficient bleeding. The sentinel skin tags and hypertrophied anal papilla at the level of the dentate line were excised, when they were present, according to Gupta and Kalaskar. ${ }^{27}$ The tissue at the base of the fissure was curetted until there were clean muscle fibers of the IAS. There was no use of diathermy and careful attention was given not to damage the IAS. Standard advancement anoplasty was performed using a flap of healthy skin tissue, which was mobilized and advanced with its blood supply to fill the defect. The flap was secured without tension to the anal canal and the skin was closed tension-free in a V-Y manner behind the advanced flap. Before surgery, all patients received a small-volume phosphate-saline enema. The metronidazole was administered intravenously with a dosage of $500 \mathrm{mg} 1$ hour before surgery and subsequently three times daily per os with a dosage of $250 \mathrm{mg}$ for 2 weeks. During the first 2 weeks after surgery, patients took a variable doses of psyllium fibers. A laxative preparation (sennosides) was given orally to subjects who had not yet passed stools 3 days after surgery. Enema, suppositories, and all rectal manipulations were avoided. Immediately after surgery, all patients received $100 \mathrm{mg}$ diclofenac intramuscularly for analgesia and they were instructed to take $100 \mathrm{mg}$ nimesulide tablets as requested and a nifedipine plus lidocaine cream three times daily until complete healing. The primary goals were the evaluation of complete fissure healing, modifications of anal pressure, and anal continence. The secondary goal included immediate and long-time complications (i.e., anal stenosis, keyhole deformity, urinary retention) that were recorded on pro forma. Complete healing was defined as complete epithelialization of the advancement skin flap. Anal incontinence was assessed preoperatively and after 1, 6, and 12 months from the surgical operation using the Pescatori ${ }^{28}$ grading system: A, incontinence for flatus and mucus; B, liquid stool; C, solid stool; and 1 for occasional, 2 for weekly, and 3 for daily. The patients were examined until they were completely healed and they were also checked at 6 and 12 months after the surgical operation. Independently of these scheduled appointments, patients were seen on request. The control group consisted of a matched 18 healthy subjects $(36.6 \pm 15.6$ years) who had previously not reported symptoms related to any anorectal diseases.

\section{Statistical Analysis}

The data were analyzed by standard statistical methods and the results were expressed as means \pm standard deviation. Differences between continuous data were compared using Student $t$ test for paired and unpaired samples, whereas differences between percentages were analyzed using Fisher test. Probability values of $<0.05$ were considered significant.

\section{Results}

Demographic and clinical characteristics of patients are reported in Table 1. 
No intraoperative complications were observed. All patients healed completely within 30 days from surgery. No cases of urinary retention, anal stenosis, or keyhole deformity were observed. No necrosis of the transposed flap was detected. The only complications, recorded postoperatively, were of slight entity and in no case required further surgery; in particular, one infection with a partial break of the donor site was detected. At 12 months follow-up, in no case was further surgery needed.

\section{Maximum Resting Pressure and Anal Continence}

In healthy control subjects, MRP and MSP values were $68.1 \pm 12.3$ (mean \pm standard deviation) and $112 \pm 36.2 \mathrm{mmHg}$, respectively. Among patients with CAF, preoperative values of MRP were significantly higher as compared with healthy subjects (98.7 \pm $18.5 ; P=0.0001$ ), whereas MSP values were only slightly increased $(127.8 \pm 31.8 ; P=0.1075)$. At 6 and 12 months after surgery, MSP values not significantly differed as compared both with preoperative levels and healthy control subjects (data not shown). At 6 months follow-up, MRP values decreased significantly with respect to the preoperative values $(P=0.0012)$ but they remained higher, even not in a significant way, as compared with healthy subjects $(P=0.0763)$. At 12 months follow-up, MRP values were higher but not significantly as compared with those observed after 6 months, but they were significantly lower as compared with baseline values $(P=0.0195)$. As compared with healthy controls, MRP values were significantly increased $(P=$ 0.0014) (Table 2).

During manometry, the presence of USWA was detected only in two of 18 healthy subjects; in patients with CAF, the USWA rate was 11 of $15(73 \%)$. A comparison among healthy subjects and patients with CAF showed a significant difference $(P=0.0004)$. Six months after surgery, the patients with USWA decreased significantly $(P=0.0092)$ with respect to preoperative assessment, whereas no differences were detected in healthy subjects. At 12 months follow-up, the subjects with USWA were lower in comparison to preoperative subjects $(P=0.0268)$ but they were not significantly higher as compared with healthy subjects $(P=0.3747)$; a comparison between 6 and 12 months showed a significant difference $(P=1)$ (Fig. 1).

Preoperatively, one patient reported anal incontinence classified as A2 according to the Pescatori grading system. After surgery, anal incontinence was present only in the patient with preoperative incontinence. At 1, 6, and 12 months follow-up, the level of incontinence in this patient was similar to preoperatively.
TABLE 1. Clinical and Demographic Characteristics of Patients with Chronic Anal Fissure

\begin{tabular}{lcc}
\hline & No. & Per cent \\
\hline Gender (male) & 15 & - \\
Age (years) & $29.3 \pm 10.2$ & - \\
Hypertrophied anal papilla & 13 & 87 \\
Skin tags & 11 & 73 \\
Symptoms & 15 & 100 \\
$\quad$ Pain & 12 & 80 \\
Bleeding & 10 & 67 \\
$\quad \begin{array}{l}\text { Pruritus } \\
\text { Duration of symptoms }\end{array} \quad$ \\
$\quad \begin{array}{l}\text { Months (mean } \pm \text { standard } \\
\quad \text { deviation) }\end{array}$ & $13.5 \pm 8.2$ & \\
\hline
\end{tabular}

TABLE 2. MRP Values Given as Mean \pm Standard Deviation in Healthy Subjects and in Patients with Chronic Anal Fissure Before and after Fissurectomy and Anoplasty

\begin{tabular}{lc}
\hline & MRP $(\mathrm{mmHg})$ \\
\hline Healthy & $68.1 \pm 12.3$ \\
Pre & $98.7 \pm 18.5$ \\
6 months & $76.3 \pm 18.3$ \\
12 months & $85.1 \pm 15.7$ \\
\hline
\end{tabular}

Student's $t$ test was used for statistical analysis. Statistical results: pre $v s$ healthy, $P=0.0001 ; 6$ months $v s$ pre, $P=$ $0.0012 ; 6$ months $v s$ healthy, $P=0.0763 ; 12$ months $v s$ healthy, $P=0.0014 ; 12$ months $v s$ pre, $P=0.0195 ; 12$ months vs 6 months, $P=0.0845$.

MRP, maximum resting pressure.

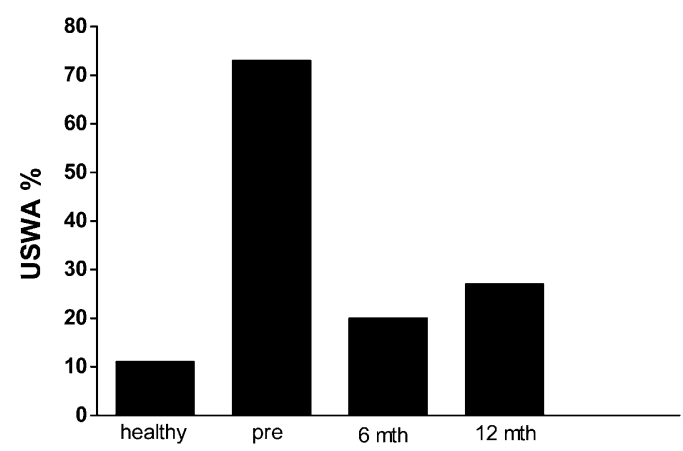

FIG. 1. Ultraslow wave activity (USWA) gave as percentage in healthy and in patients with chronic anal fissure (CAF) before and after fissurectomy and anoplasty. Fisher test was used for statistical analysis. Statistical results: pre $v s$ healthy, $P=0.0004 ; 6$ months vs pre, $P=0.0092,6$ months $v s$ healthy, $P=0.6390,12$ months $v s$ healthy, $P=0.3747,12$ months $v s$ pre, $P=0.0268,12$ months $v s$ 6 months, $P=1$.

\section{Discussion}

The results obtained show that fissurectomy and anoplasty with advancement flap is a surgical procedure that allows a high incidence of fissure healing and a low incidence of complications with no alterations of anal continence. At 6 months follow-up, MRP values were lower than preoperative values and similar as compared 
with healthy subjects; at 12 months, they were slightly higher with respect to those detected after 6 months follow-up, remaining more as compared with preoperative values although they were higher than healthy subjects. These results are similar to the results obtained after lateral internal sphincterotomy ${ }^{29}$ and after pneumatic balloon dilatation. ${ }^{30}$

The aid of CAF treatment is in healing the patient without immediate or long-time complications. Anal incontinence, even if regarding only gas, is the most serious complication that can compromise quality of life and it can be more disabling than CAF. The anal incontinence can occur immediately or at a long distance after surgery and it can be temporary or permanent. The incidence of incontinence postsphincterotomy or stretch of the IAS varies from zero in some studies reaching up to 31 per cent in other cases. ${ }^{31}$ This extreme variability can depend on the extent of sphincterotomy, the definition of anal incontinence, and the differences in followup. ${ }^{32}$ Pernikoff et al. ${ }^{33}$ found that fecal incontinence after internal sphincterotomy became more common with time. Casillas et al. ${ }^{31}$ reported 298 patients who underwent a sphincterotomy for CAF with a mean follow-up of 4.3 years reporting temporary incontinence in 31 per cent and persistent gas incontinence in 30 per cent. In a recent study, Levin et al. ${ }^{34}$ showed that the incidence of the first anal incontinence event in approximately 5.5 per cent of patients at least 4 years after surgery.

IAS has an essential role to preserve anal continence. The injury of the IAS can be functionally compensated immediately after surgery. However, in some patients, progression from functionally compensated to functionally uncompensated anal sphincter damage may occur. ${ }^{34}$ Delayed incontinence may be associated with other cofactors accumulating over time, or more likely, anal fissure surgery may accelerate the physiological age-related weakening of the anal sphincter mechanism.

The role of hypertonia of the IAS in pathogenesis of the CAF remains unclear. Several studies showed that a reduction of MRP levels with medical therapy is associated with a high incidence of fissure healing. However, Pitt et al., ${ }^{35}$ in a double-blind randomized placebo-controlled trial, observed that oral indoramin $(\alpha$-adrenoreceptor antagonist) reduced MRP but had no satisfactory effect on fissure healing. Other studies $^{36-38}$ confirmed no significantly differences between healing and not healing CAF when manometric findings were compared. Recently, some surgical procedures such as fissurectomy alone or fissurectomy associated with advancement flap showed a similar incidence of fissure healing compared with the sphincterotomy or the anal dilatation. According to these observations, a reduction of anal pressure as a consequence obtained with pharmacological or surgical therapy does not represent a prerequisite for CAF healing. ${ }^{39}$
During the fissurectomy with or without advancement flap, some steps may compromise the integrity of the IAS. Therefore, it is necessary to perform a fissurectomy with a scalpel to avoid excision or cauterization of the IAS fibers. Also, anal retractors (Parks, Eisenhammer, Fergusson) have not been used; when it became necessary, they have been used slightly and for a short period of time. Zimmermann et al., ${ }^{40}$ in a prospective randomized clinical trial showed, that patients, treated with a transanal advancement flap for repair of a high transsphincteric fistula, have a significant reduction of MRP and an increase of anal incontinence after use of a Parks retractor as compared with use of a Scott retractor. ${ }^{40}$ Van Tets et al. ${ }^{41}$ who have conducted a study in patients who underwent closed hemorrhoidectomy showed that the reduction of MRP was, respectively, 23 and 8 per cent in ratio of the use or not the use of a Parks retractor, respectively. Van Test et al. ${ }^{41}$ suggested that overstretching of the anal sphincters by a Parks retractor results in rupture of small nerve branches and consequently to denervation of muscle fibers. In animal studies, it has been shown that prolonged stretching can lead to local necrosis of external anal sphincter fibers. ${ }^{42}$ In this study, a good exposure of anal canal was obtained using four Kocher pliers at 3, 6, 9, and 12 hours, respectively, to avoid the use of an anal retractor.

In conclusion, the fissurectomy with anoplasty resulted in an high fissure healing rate reporting no case of fecal incontinence at 2 years follow-up. In addition, this procedure resulted in being able to reduce IAS pressure in the same manner of the partial or total sphincterotomy or forceful anal dilatation.

\section{REFERENCES}

1. Hospital Episode Statistics. 2007. Hospital Episode Statistics 2005/2006. Department of Health. National Institute for Health and Clinical Excellence. Available at: www.hesonline.nhs.uk. Accessed March 5, 2011.

2. Annual Report SICCR. 2009. Available at: www.siccr.org. Accessed February 26, 2011.

3. Collins EE, Lund JN. A review of chronic anal fissure management. Tech Coloproctol 2007;11:209-23.

4. Aigner F, Conrad F. Fissurectomy for treatment of chronic anal fissures. Dis Colon Rectum 2008;51:1163.

5. Meier zu Eissen J. Chronic anal fissure, therapy. Kongressbd Dtsch Ges Chir Kongr 2001;118:654-6.

6. Mousavi SR, Sharifi M, Mehdikhah Z. A comparison between the results of fissurectomy and lateral internal sphincterotomy in the surgical management of chronic anal fissure. J Gastrointest Surg 2009; 13:1279-82

7. Engel AF, Eijsbouts QA, Balk AG. Fissurectomy and isosorbide dinitrate for chronic fissure in ano not responding to conservative treatment. Br J Surg 2002;89:79-83.

8. Sileri P, Stolfi VM, Franceschilli L, et al. Conservative and surgical treatment of chronic anal fissure: prospective longer term results. J Gastrointest Surg 2010;14:773-80. 
9. Lindsey I, Cunningham C, Jones OM, et al. Fissurectomybotulinum toxin: a novel sphincter-sparing procedure for medically resistant chronic anal fissure. Dis Colon Rectum 2004;47:1947-52.

10. Baraza W, Boereboom C, Shorthouse A, Brown S. The long-term efficacy of fissurectomy and botulinum toxin injection for chronic anal fissure in females. Dis Colon Rectum 2008;51: 239-43.

11. Scholz T, Hetzer FH, Dindo D, et al. Long-term follow-up after combined fissurectomy and Botox injection for chronic anal fissures. Int J Colorectal Dis 2007;22:1077-81.

12. Arthur JD, Makin CA, El-Sayed TY, Walsh CJ. A pilot comparative study of fissurectomy/diltiazem and fissurectomy/ botulinum toxin in the treatment of chronic anal fissure. Tech Coloproctol 2008;12:331-6.

13. Aivaz O, Rayhanabad J, Nguyen V, et al. Botulinum toxin A with fissurectomy is a viable alternative to lateral internal sphincterotomy for chronic anal fissure. Am Surg 2009;75:925-58.

14. Patti R, Famà F, Barrera T, et al. Fissurectomy and anal advancement flap for anterior chronic anal fissure without hypertonia of the internal anal sphincter in females. Colorectal Dis 2010; 12:1127-30.

15. Patti R, Famà F, Tornambè $\mathrm{A}$, et al. Early results of fissurectomy and advancement flap for resistant chronic anal fissure without hypertonia of the internal anal sphincter. Am Surg 2010; 76:206-10.

16. Giordano P, Gravante G, Grondona P, et al. Simple cutaneous advancement flap anal advancement flap for resistant chronic anal fissure: a prospective study. World J Surg 2009;33: 1058-63.

17. Chambers W, Sajal R, Dixon A. V-Y advancement flap as first-line treatment for all chronic anal fissures. Int J Colorectal Dis 2010;25:645-58.

18. Patel SD, Oxenam T, Praveen BV. Medium term results of anal advancement flap compared with lateral sphincterotomy for the treatment of anal fissure. Int J Colorectal Dis 2011;26:1211-4.

19. Nyam DC, Wilson RG, Stewart KJ, et al. Island advancement flaps in the management of anal fissures. Br J Surg 1995;82: 326-8.

20. Pescatori M, Ayabaca SM, Cafaro D. Tailored sphincterotomy or fissurectomy and anoplasty? Dis Colon Rectum 2002;45: $1563-4$.

21. Kenefick NJ, Gee AS, Durdey P. Treatment of resistant anal fissure with advancement anoplasty. Colorectal Dis 2002;4:463-6.

22. Singh M, Sharma A, Gardiner A, Duthie GS. Early results of a rotationalflap to treat chronic anal fissures. Int $\mathrm{J}$ Colorectal Dis 2005;20:339-42.

23. Samson RB, Stewart WR. Sliding skin grafts in the treatment of anal fissures. Dis Colon Rectum 1970;13:372-5.

24. Hancke E, Rikas E, Suchan K, Volke K. Dermal flap coverage for chronic anal fissure: lower incidence of anal incontinence compared to lateral internal sphincterotomy after long-term follow-up. Dis Colon Rectum 2010;53:1563-8.

25. Ouaïssi M, Giger U, Sielezneff I, et al. Mucosal advancement flap anoplasty for chronic anal fissure resistant to conservative therapy. World J Surg 2011;35:900-4.
26. Jones OM, Ramalingam T, Lindsey I, et al. Digital rectal examination of sphincter pressures in chronic anal fissure is unreliable. Dis Colon Rectum 2005;48:349-52.

27. Gupta PJ, Kalaskar S. Removal of hypertrophied anal papillae and fibrous anal polyps increases patient satisfaction after anal fissure surgery. Tech Coloproctol 2003;7:155-8.

28. Pescatori M, Anastasio G, Bottini C, Mentasti A. New grading and scoring for anal incontinence. Evaluation of 335 patients. Dis Colon Rectum 1992;35:482-7.

29. Ram E, Alper D, Stein GY, et al. Internal anal sphincter function following lateral internal sphincterotomy for anal fissure: a long term manometric study. Ann Surg 2005;242:208-11.

30. Renzi A, Izzo D, Di Sarno G, et al. Clinical, manometric, and ultrasonographic results of pneumatic balloon dilatation vs. lateral internal sphincterotomy for chronic anal fissure: a prospective, randomized, controlled trial. Dis Colon Rectum 2008;51:121-7.

31. Casillas S, Hull TL, Zutshi M, et al. Incontinence after a lateral internal sphincterotomy: are we underestimating it? Dis Colon Rectum 2005;48:1193-9.

32. Garcia-Granero E, Sanahuja A, Garcia-Botello SA, et al. The ideal lateral internal sphincterotomy: clinical and endosonographic evaluation following open and closed internal anal sphincterotomy. Colorectal Dis 2009;11:502-7.

33. Pernikoff BJ, Eisenstat TE, Rubin RJ, et al. Reappraisal of partial lateral internal sphincterotomy. Dis Colon Rectum 1994;37: 1291-5.

34. Levin A, Cohen MJ, Mindrul V, Lysy J. Delayed fecal incontinence following surgery for anal fissure. Int J Colorectal Dis 2011;26:1595-9.

35. Pitt J, Dawson PM, Hallan RI, Boulos PB. A double-blind randomized placebo-controlled trial of oral indoramin to treat chronic anal fissure. Colorectal Dis 2001;3:165-8.

36. Ho YH, Tan M. Ambulatory anorectal manometric findings in patients before and after haemorrhoidectomy. Int J Colorectal Dis 1997;12:296-7.

37. Thornton MJ, Kennedy ML, King DW. Prospective manometric assessment of botulinum toxin and its correlation with healing of chronic anal fissure. Dis Colon Rectum 2005;48:1424-31.

38. Pascual M, Pera M, Courtier R, et al. Endosonographic and manometric evaluation of internal anal sphincter in patients with chronic anal fissure and its correlation with clinical outcome after topical glyceryl trinitrate therapy. Int J Colorectal Dis 2007;22: 963-7.

39. Madalinski MH. Identifying the best therapy for chronic anal fissure. World J Gastrointest Pharmacol Ther 2011;6:9-16.

40. Zimmermann DD, Gosselink MP, Hop WC, et al. Impact of two different types of anal retractor on fecal continence after fistula repair: a prospective, randomized, clinical trial. Dis Colon Rectum 2003;46:1674-9.

41. Van Tets WF, Kujipers JH, Tran K, et al. Influence of Parks' anal retractor on anal sphincter pressures. Dis Colon Rectum 1997; 40:1042-5.

42. Li L, Zhang JZ, Lu GW, et al. Damaging effects of anal stretching on the external anal sphincter. Dis Colon Rectum 1996; 39:1249-54. 
Reproduced with permission of the copyright owner. Further reproduction prohibited without permission. 